\title{
Frameless
}

Volume 1 | Issue 1

Article 15

November 2019

\section{Three Simple Stories About Power}

Eli Kuslansky

Unified Field, info@kuslanskyelectric.com

Follow this and additional works at: https://scholarworks.rit.edu/frameless

\section{Recommended Citation}

Kuslansky, Eli (2019) "Three Simple Stories About Power," Frameless: Vol. 1: Iss. 1, Article 15.

DOI: 10.14448/Frameless.01.002

Available at: https://scholarworks.rit.edu/frameless/vol1/iss1/15

This Keynote Address is brought to you for free and open access by RIT Scholar Works. It has been accepted for inclusion in Frameless by an authorized editor of RIT Scholar Works. For more information, please contact ritscholarworks@rit.edu. 


\title{
FRAMELESS
}

\section{Three Simple Stories About Power}

\author{
Eli Kuslansky \\ Keynote Speaker, Frameless Symposium 2018 \\ Partner and Chief Strategist, Unified Field, New York, NY
}

At this symposium, I thought I would like to share three simple stories about culture and power that have inspired me since I first started in this field some thirty years ago. I hope these stories will inspire you as well. Some of the content here I've written about before, but I've added some new details about and snippets from my personal life experience.

My first story is about a famous Yiddish writer, wild energy and the power of viral networks.

In the early twentieth century in Russia, there was an author and playwright named Solomon Naumovich Rabinovich, better known as Sholem Aleichem, a pseudonym he took that in Hebrew means "peace be with you." He wrote stories about Jewish life in Eastern Europe. His most famous stories were about Tevye the Dairyman, a series he wrote over twenty years, about his life and the life of his daughters. It eventually was made into the successful Broadway musical Fiddler on the Roof.

When Sholem Aleichem was a young man, he met a wealthy landowner who asked him to tutor his daughter, Olga. Eventually he married her gaining the financial freedom he needed to write. Of course, being a writer, he lost the entire family fortune in a bad stock deal but that's another speech. In Russia in the early twentieth, a writer had three choices of language. Russian, which was the language of great writers like Dostoevsky, Pushkin and Checkov: Hebrew, which was considered the "divine language of God", and Yiddish, which was called "mamaloshen", or the "mother's tongue", which was the language of the street, commerce and gossip.

Sholem Aleichem made a very interesting choice by writing in Yiddish. As he said, writing in Yiddish was crazy (mashugana), but he also felt it was very freeing - like a form of wild energy in a fertile field. Because his stories were written in Yiddish and were based on in everyday Jewish life, they became so wildly popular with a network of Jewish merchants and families around the globe and they spread like wildfire. For many of these Jews, living in far off lands, having these stories was like having a portable homeland that spanned time and distance.

So why we would care about a Yiddish writer who died over 90 years ago? You could say that the wild energy that swiftly carried Sholem Aleichem's stories around the world was an early viral network. We still see this dynamic at play today. 
In the era of Instagram and YouTube, there are other forms of wild energy and crowdculture. In the last several years, companies made huge bets creating and inserting branded content throughout the digital universe. Their thinking was if you told customers great stories and then connected with them in real time, their brand would become a hub for a community of consumers. But despite making huge bets on branded content and investing billions of dollars in content creation, companies got very little payoff or generated any meaningful consumer interest. In fact, social media seems to have made these brands less significant not more. So, what was missing from this picture?

While major brands were struggling with branded content, digital technologies created potent new social networks that dramatically altered how culture works. The most effective and prolific innovators of new forms of culture are digital crowds, a social media phenomenon that Douglas Holt called crowdculture. Douglas Holt is a former professor at the Harvard Business School, and a world leading expert on branding and innovation. So why is it that branded-content strategies don't work and crowd-culture does?

Crowd-culture comes in two flavors, turbocharged art worlds and amplified subcultures. In turbocharged art worlds, millions of nimble cultural entrepreneurs come together online to improve their skills, exchange ideas, fine-tune content, and compete to produce hits. This collective effort often generate major creative breakthroughs. Of hundreds of amplified subcultures that crowd-culture has created, one of them is gaming comedy. Gaming comedy came out of the videogaming-as-entertainment subculture of South Korea that went global and produced the massive spectator E-sports competitions. E-sports competitions currently have over 143 million online viewers worldwide. Esports gave birth to video commentators like PewDiePie, the most-subscribed user on YouTube. PewDiePie is a pseudo name for Felix Arvid Ulf Kjellberg, a 29-year-old Swedish comedian and YouTube celebrity known for snarky video game commentaries, particularly of the horror genre. To give you a sense of the power of crowd-culture, PewDiePew makes extremely inexpensive videos, in his house, yet has 71 million subscribers and billions of hits. Compare this to some of the major brands that are spending millions of dollars on social media and have under a million subscribers at best.

What are the wild energies of today? Along with artworlds and subcultures there are the emerging fields of augmented and virtual reality, AI, natural language processing, machine learning, ambient sensors, big data, legible cities, intelligent buildings, and advanced 3D printing. Other forms of wild energy include the culture of generation $\mathrm{Z}$ the generation after millennials, that are the true digital natives. This generation expects everything to be interactive and available 24/7. They have limited faith in traditional organizations, and they experience the word augmented, virtually and corporeally.

As the boundaries between digital and physical blur, new sources of wild energy are emerging at a dizzying pace. Yet detecting and harnessing wild energy is a challenge. They are ambient, fluid, and interconnected in nature so finding them can be counter intuitive. But once you can distinguish a wild energy and connect to it, it's like riding a self-sustaining, high-speed carrier wave that multiplies an idea's effect at lightning 
Vol. 1, No. 1 - 2019

Frameless

speed. Distinguishing a wild energy takes a special kind of listening which brings us to our next story.

\section{The Power of Serendipity}

This is story about Leó Szilárd, the forgotten father of the atomic bomb, and the power of serendipity.

On a rainy London street corner, on the autumn morning of September 12, 1933, the Hungarian physicist Leó Szilárd was waiting for a light to change from red to green. $\mathrm{He}$ was deep in thought and irritated about an article that he had just read in The London Times. The article described a lecture given by Ernest Rutherford, the father of nuclear physics, who said that "anyone who believed that nuclear reactions would be a potent source of useful energy was talking moonshine". Szilárd was pissed, as how could anyone be so positive about the future of energy, yet so wrong.

As the light change from red to green, Szilárd stepped off the curb, and in a flash, realized how to create a nuclear chain reaction that would release the enormous amount of energy needed for an atomic bomb. As Szilard later recounted the story, when he reached the intersection of Southampton Row and Russell Square a red light caused him to pause, giving time for his fertile imagination to engage.

Six years later when the Nazis split the atom and invaded Czechoslovakia for their uranium, Szilárd, realizing the scientific and geopolitical implications, wrote a letter to Franklin Delano Roosevelt warning him that the Nazis were building an atomic bomb. But because he was not as well-known as his friend Albert Einstein was, he asked him to sign the letter instead. It was an irritating moment at a traffic light on a rainy London street that started the chain of events that lead to the atomic bomb. This is the power of serendipity. Serendipity has a lighter side as well. Serendipity is looking for one thing and stumbling across something else of equal or greater value. It is the engine for innovation. Rubber, dynamite, the atom bomb, Kandinsky's discovery of abstract art, X-rays, and even Post it notes were all discovered by accident. Serendipity is a misadventure. It's the inadvertent observation. It's a happenstance that occurs that when a smart mind is opened to the unforeseen and finds the true power of innovation. But you have to listen actively for it.

Which brings me to the story of the power of active listening, which is also the story of assumption busting.

After graduating from The Cooper Union for the Advancement of Science and Art as a photography and sculpture major, my first job at the South Street Seaport Museum was as a store manager, exhibition designer and curator. I was green and they were cheap, so I wore many hats. One of the things I did was appraisals of historical model ships for Sotheby's, one of the leading international auction houses.

As an appraiser, I got to know and befriended Hugh Hildesley, Sotheby's Executive Vice President and world-leading expert in European Master paintings. He was an older man when I met him and had worked at Sotheby's for many years. After leaving South Street, I reached out to him, we had not spoken for many years When I phoned, the receptionist I spoke to at Sotheby's told me that Mr. 
Hildesley was no longer with them and he had moved on to the Church of Heavenly Rest. Shocked, I said "my god, what did he die of" to which she replied, "well, nothing, he's not dead, he's now a rector at the church."

Assumptions can produce weird results and unintended consequences. Listening isn't just listening to words or music, but to listening to what people are saying and not saying. Listening for their reactions, to their underlying narratives, and to their pregnant silences. In business, it's listening to industry trends, the ambience of an environment, or what your colleagues, customers and managers are really trying to tell you though it might not be something that you want to hear.

In the creative arts it is listening to your authentic self, the beliefs, culture and events that make you who you are, and the ground you need to stand on. Listening to your roots is also listening to the wellspring of your creativity. In my own life I can trace that moment that spot-welded my interest in art, science and media. Growing up in Brooklyn my family owned a wholesale and retail electrical supply company in Williamsburg. Williamsburg then was not the Williamsburg we know today. At that time hip was just a body part.

My family owned two stores, side by side and connected by a door. One was the electrical supply store that sold cables, lights, hardware, fixtures, and outlets. The sister store was a lighting showroom. For my brother, sister, and I, it was the lighting showroom that fascinated us. It was a space about 15 , $x$ 40'x 10' high, with a tin ceiling and was piled floor-to-ceiling with chandeliers, floor lamps, pendants and table lamps, all lit up and glowing like a Christmas display on speed. Midway, on one wall, was a series of 12' long shelves on which were displayed complete sets of Lionel $\mathrm{O}$ scale trains. For those who are not familiar, an $\mathrm{O}$ scale steam engine can easily measure 24" long. For us that showroom was magical.

That simple act of walking through a door from the functional mundane world of electrical supplies into a space of light and imagination instilled in me a sense of wonder, an ability to gauge scale, and an appreciation for the power of surprise. These are the same qualities we use in developing in our projects at our firm, Unified Field and the same qualities I call upon when creating artwork. The gift I received from that experience, so many years ago, is that the power of connecting to your roots, grounds you in your authenticity.

\section{The Power of Surprise}

The keys to connecting to your roots is actively listening and a willingness to challenge your assumptions. At Unified Field, in our ideation sessions with our clients, we do an exercise in thinking in opposites that we call The Absolutely Worst Idea Possible.

The thinking behind the exercise is that when most of us are given a task, we tend to jump right in and try to "get it right." This puts a lot of pressure on us and is often not an effective strategy for generating original ideas. We tend to base our first ideas on a set of deeply-held, unspoken beliefs or assumptions. This not only stifles creativity, but ideal, and far reaching solutions are often overlooked. Thinking "in opposite" can generate surprising results. Many bad ideas contain the "seeds" of good ones. 
The way the Absolutely Worst Idea Possible exercise works is that individuals in a team determine an outcome that they are trying to achieve, and then each one writes down their twenty worst ideas. We're going for bad, ineffective, stupid, illegal, gross ideas here. Then everyone shares their ideas with the group, and we then challenge each other to come up with even worse ideas than originally created. From this list, the group selects the ones they like best and then flips them around to formulate positive ideas.

We completed this exercise with a client from a leading technology company. The team used their exhibit booth for the workshop scenario. The worst ideas for the booth ranged from refusal to talk with anyone, punching people in the face, exhibiting naked from the waist down, and my personal favorite - slaughtering livestock in the booth. You can imagine how funny this was, as halfway through the exercise everyone was in tears from laughing.

In the second round, slaughtering livestock transitioned from bad to worse as it evolved into human sacrifices in the booth. Now on the face this sounds a bit insane, but if you look it metaphorically, what's behind this idea is ritual. For the exhibit booth what emerged was a yearly ritual of hosting a cool, "must-go-to" party for select clients that increased their exposure and business goals substantially.

Busting assumptions is one way to come up with something original, but it cannot be accomplished without active listening. It is only through active listening that we can accurately receive and interpret messages in communications and environments. We see this pattern a lot in the future of culture, in science centers and museums who are well served when they listen to the massive changes in technology, demographic shifts, and audience behaviors. We see this in the future of retail where they need to merge physical and digital experiences to meet customers where they are at. We see it in many organizations that need to go digital by listening from the outside in, not the inside out.

We find this dynamic in developers and creatives as well. When they present their ideas to key stakeholders, they tend to focus on cool features and technologies. But it is not the features and the technology that gets a project approved. For any project, be it virtual or augmented reality, interactive, themed, or linear, what makes it happen is being present to who you are presenting to and how it will resonate in the world. It means listening to audience and stakeholder needs and values while promoting the benefits that your creations will bring them. This is the world in which amazing projects are realized.

Be open

Be vulnerable

Be out there. 